\title{
Papers
}

\section{Simplicity, security and choice: Which option do you choose?}

Received: 5th March, 2003

\section{Bill Birmingham}

After graduating from the University of Manchester, Bill Birmingham worked for 25 years for the Department of Social Security, mainly in the fields of occupational pensions policy and the application of European Community legislation in the pensions and social security fields. He was subsequently Manager of Benefit Services and Head of Research for the National Association of Pension Funds. He has participated in projects to advise the Governments of Russia, China, Hungary and Kyrgyzstan in the field of social security and pension policy development and regulation and has undertaken pensions training for Crown Agents Financial Services Ltd in the UK and several African states. He is now a consultant with the actuarial firm, Lane Clark \& Peacock LLP.

Bill Birmingham Lane Clark \& Peacock, 30 Old Burlington Street, London WIX 2NN, UK.

Tel: +44 (0)20 7432 6682; E-mail:

bill.birmingham@lcp.co.uk

Abstract In December 2002 the UK Government published simultaneously a Green Paper, which outlined proposals for possible changes to, and simplification of, statutory provisions applicable to occupational pension schemes; and a consultation paper, which proposed radical changes to the statutory basis for the taxation of pension schemes and pension benefits. This paper examines the proposals put forward in the former, identifies suggested options for change, and comments on the impact which adoption of the different alternatives might have on future pension arrangements and design.

Keywords: UK Government; Department for Work and Pensions; Green Paper; scheme-specific funding requirement; contracting out; winding-up; TUPE; vesting; simplification

\section{Introduction - The Green Paper}

Recently the Government got itself into trouble when an adviser suggested bringing out bad news on a day when it would be overshadowed by other considerably more important news. The problem for the Department for Work and Pensions (DWP) was rather different. It brought out its pensions Green Paper, 'Simplicity, security and choice: Working and saving for retirement ${ }^{\text {'1 }}$ and the accompanying technical paper $^{2}$ on the same day, 17th December, 2002, as the Treasury and Inland Revenue published their consultation paper on tax simplification. ${ }^{3}$ While the Green Paper was the obverse of the Government's proposals, the reverse side of the coin, the tax paper, shone out, rather putting the Green Paper into the shade.

It was unfortunate, and perhaps unfair to the DWP that, whereas the tax paper was greeted with almost universal acclamation, the Green Paper was described in the pension press as 'a bit of a damp squib'. Certainly it did not provide the radical transformation of pensions legislation that the DWP's Inland Revenue colleagues had come up with.

A Green Paper is by its nature a discussion document. The Government's definitive proposals appear in a White Paper. For the Green Paper to have been more clear-cut could rightly have led to 
complaints that it was not really a Green Paper at all and that the pensions world had been denied the opportunity to comment and make suggestions before the proposals had been set in concrete.

As with all such documents published by governments of all persuasions, the document started with a description of the great things that the Government had done in the pensions field since taking office. The Green Paper itself dealt with proposals basically in four categories: first, a confirmation of proposals that already had been announced; secondly, reasons for rejecting certain of the proposals put forward by Alan Pickering in his report; ${ }^{4}$ thirdly, a number of options on issues where the objective had been determined, but how best to achieve it was still 'up for grabs'; and fourthly, where the DWP effectively says, 'We are not sure what to do. Please help us.'

The pensions world should be grateful for, and use, the opportunity to ensure that what is proposed is workable, is in the best interests of pension scheme administration and removes the complexity and unnecessary administrative costs that much pensions legislation imposes. However, the pensions world is right to regret that the DWP is scared of the wholesale radicalism of the Inland Revenue.

\section{The Green Paper's proposals}

What therefore does the Green Paper propose and will it simplify life for pension schemes?

\section{Scheme-specific funding requirements}

The Government's decision to replace the existing minimum funding requirement (MFR) provisions by a scheme specific funding requirement is not new, as it was announced two years ago. Under the proposed new arrangements, each defined benefit (DB) scheme will be required to determine its own approach to funding and to set this out in a Statement of Funding Principles (SFP). The SFP will be drawn up by the trustees with the agreement of the employer, on the advice of the scheme actuary. It will set out the scheme's strategy for funding its liabilities and correcting any funding deficits and will have to be made available to members on request. In addition, trustees will have to send to members automatically, and possibly annually, a document containing key information about the scheme's funding position, including the funding level at the last full valuation, the current contributions level and, where applicable, what is being done to correct any deficit.

Actuarial valuations will still have to be carried out every three years.

Valuation reports will, as now, contain an explanation of the funding methods, assumptions used and implications for future contribution rates. Following the valuation the trustees will be required, as now, to prepare a schedule of contributions to which the employer must agree and the scheme actuary will certify that the contributions specified are adequate to satisfy the funding principles. Where there is a deficit, the period over which the deficit is to be eliminated will be scheme specific and determined by the trustees with the agreement of the employer, in accordance with the SFP and based on advice by the scheme actuary. Scheme actuaries and auditors will continue to be required to 'whistleblow' to the pensions regulator on non-payment of contributions and failure to obtain a funding valuation or schedule of contributions, but they will also have to report a failure to produce a SFP within a prescribed time. (It is unclear how this equates with the proposal elsewhere in the Green Paper to 
remove time limits for disclosure requirements.)

Where the trustees and employer cannot reach agreement, the trustees will be given an overriding power to freeze or wind up the scheme. The Faculty and Institute of Actuaries will issue a new guidance note 'to assist the actuary in carrying out his or her professional duties'.

In advance of the introduction of the scheme-specific funding arrangements, scheme trustees will need to consider with the scheme actuary to what extent the scheme actuary will operate differently under the new arrangements from those currently applicable. The scheme actuary must advise the trustees on the funding principles to be adopted for the SFP and on the appropriate length of time for any deficit to be eliminated. It is unclear at this stage to what extent the extra functions placed on the actuary will alter the relationship between the scheme actuary and the trustees if, as a result of the scheme actuary's advice, the trustees adopt a policy and practice that lead to scheme insolvency.

It is possible that the new arrangements will lead the scheme actuary to adopt a more cautious approach to assumptions regarding, for instance, investment returns and to advice about investment strategy to avoid any possible subsequent comeback, if the strategy ultimately turns out to have been inappropriate. Such a cautious approach to assumptions could, as a consequence, lead to a requirement for higher contribution rates.

Employers too may wish to obtain independent actuarial advice before deciding whether to agree to the principles in the SFP and the contribution rates in the schedule of contributions, on which the trustees have obtained advice from the scheme actuary.
If they do, and the advice they receive differs from that provided to the trustees by the scheme actuary, this could lead to stalemate between employer and trustees.

\section{Contracting out (and limited price indexation (LPI) for contracted-in schemes)}

\section{The principle of contracting out}

DWP has stated its intention to maintain the principle of contracting out of the state second pension scheme ( $\mathrm{S} 2 \mathrm{P})$, formerly the state earnings-related pension scheme (SERPS). However, employers will need to consider whether, with the possible changes of scheme design in the light of the Inland Revenue's taxation proposals, the reasons for an employment to continue to be contracted out still apply. Any decision on whether to continue to contract out may be influenced by rebate levels, so far unknown, following the introduction of the proposed changes to the contracting-out requirements. Other factors include the extent to which any administrative easements resulting from the Green Paper reduce the administrative cost and activity. It may be that with an increasing number of schemes choosing to contract in, the DWP may be forced to consider in the not too distant future whether the cost and complexity of the contracting out arrangements continues to be justified.

\section{Survivors' benefits and LPI}

The Government has rejected the Pickering recommendation that it should no longer be a condition for contracting out for schemes to have to provide survivor's benefits and LPI. The Green Paper states that the Government would not introduce changes in these areas unless it had good reason to believe that 
coverage and contributions would be higher than would otherwise be the case. Although the Government has invited comments on the issue, it seems very unlikely that anyone will produce sufficient evidence to cause the Government to change its mind.

Nevertheless, the Green Paper floats the possibility of removing the requirement for LPI to the extent that pensions exceed $\mathcal{E}^{3} 30,000$ p.a., which would in the Government's opinion affect only about 5 per cent of retiring pensioners. This may be intended to complement the proposal (see below) to remove the priority on wind-up of the excess over $£ 30,000$ p.a. of pensions in payment. However, it seems unlikely that the removal of an LPI for pensions over $\mathcal{E}^{30,000}$ will lead to an increase in occupational pension coverage. Members with a pension of over $£ 30,000$ p.a., however, might choose to forego LPI over $\mathcal{E}^{3} 30,000$, if they could have a higher initial pension rate.

\section{Reference scheme test}

The Government proposes to amend the reference scheme test (RST) for contracted-out salary-related schemes (COSRS) by reducing the accrual rate, expanding the definition of qualified earnings and permitting career average schemes to satisfy the RST. The proposed changes and likely effect are outlined in Table 1.

Under current arrangements a scheme is deemed to have met the RST if it provides pension benefits which, for at least 90 per cent of individual members, are broadly equivalent to (or better than) the RST minimum. (This allows schemes some flexibility; under the reformed RST this flexibility would be extended in line with the Pickering recommendation by reducing the 90 per cent to 80 per cent.)
Apart from the possibility of some career average schemes currently unable to be used for contracting out becoming so, it seems unlikely that the proposed packages of changes to the reference scheme test will act as an incentive to more schemes to contract out, or a disincentive to employers with existing COSRS from either contracting in, or closing or winding up their COSRS.

\section{Simplification of GMPs and 'anti-franking'}

The Government did not put forward any concrete proposals in the Green Paper for simplifying guaranteed minimum pensions (GMPs), nor for dealing with the consequential anti-franking provisions (apart from continuing to delay the commencement of the alternative to anti-franking under the 2000 Act). ${ }^{5}$ However, it has subsequently put forward three possible ways of dealing with GMPs. These are:

- abolition of the requirement to pay GMPs

- conversion of GMPs to scheme benefits

- transfer of GMPs back into the state system (SERPS/S2P).

It is also inviting other possible alternatives to be put forward.

The solution could either be compulsory, requiring all schemes to adopt a standard pattern, or voluntary, leaving it to schemes to decide whether to opt for an alternative. There could be a single alternative, or a number of alternatives, either freely available, or with some limited to particular circumstances, eg wind-up. If a voluntary approach were adopted, those schemes that did not adopt it would remain subject to existing requirements, including anti-franking. 
Table 1:

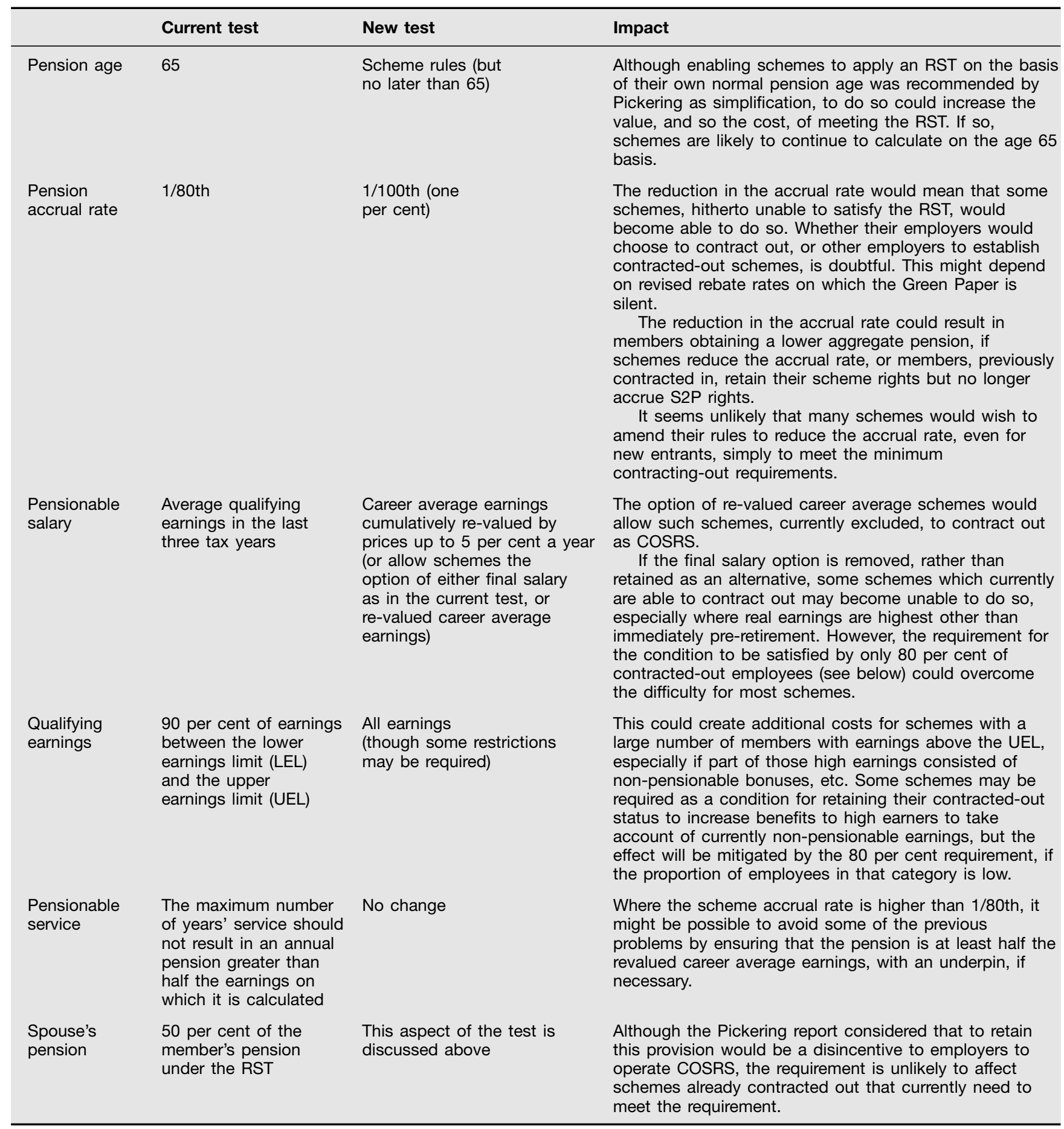

\section{Option of abolition of GMPs}

Under this option, legislation would remove the requirement for schemes to pay GMPs, but members would still have a liability to entitlement under scheme rules and other statutory requirements. Revaluation would be as for other rights, instead of the s. 148 
or fixed-rate revaluation. All pensions in payment would become subject to standard indexation in accordance with scheme rules, subject to LPI. Increases would be higher than the current GMP indexation requirement. On wind-up the position of GMPs in the wind-up priority order would disappear. Instead, rights, in respect both of pensions in payment and those accrued rights not in payment, would revert to the current level of non-GMP pre-1997 rights.

The abolition of GMPs would, without further legislation, remove the statutory requirement to provide a widow's or widower's benefits in respect of pre-1997 service. The Government has already stated its unwillingness to abolish benefits to surviving spouses. It is assumed that, if this option were chosen, a requirement for pre-1997 widows and widowers would be enacted.

Even though GMPs would be abolished under this option, the Government would wish to avoid double provision for pensioners who have benefited from contracted-out National Insurance contributions (NICs). There would probably, therefore, need to be a requirement for the Inland Revenue to keep a record of notional GMPs so that a contracting-out deduction could be made from the pensioner's SERPS/S2P.

Currently as a condition of contracting out, the Pension Schemes Act 1993 requires COSR schemes to provide a rule to the effect that the weekly rate of a member's pension will be not less than the guaranteed minimum. Repeal of the statutory requirement to provide GMPs would not of itself remove the provision in scheme rules that the pension should not be less than the GMP level. Section 67 of the Pensions Act 1995, which the Government proposes to modify only so far as to permit without consent de minimis rationalisations of existing rules, would in most cases prevent schemes from retrospectively removing without consent the requirements under the existing rules. However, repeal of the requirement to provide GMPs would mean the abolition of the anti-franking requirements.

\section{Option of conversion of GMPs}

Under this option schemes would be permitted to convert their GMP liabilities into normal scheme benefits on the basis of actuarial equivalence. If so, the DWP has raised the issue of whether any such conversion should be permitted only with consent, or without consent, thereby requiring a disallowance of section 67 of the Pensions Act 1995. Equally, the DWP raises the question whether schemes should be permitted to convert certain, eg widow's deferred rights, but not all, GMP rights.

Conversion would mean for deferred members a revaluation by the retail price index (RPI) to 5 per cent, which in many cases could be less than the member's fixed rate conversion percentage, but actuarial equivalence would therefore require some additional benefit. For some pensioners, indexation of former GMPs, in accordance with scheme rules, could be lower than the current RPI to 3 per cent. On wind-up, the priority of accrued rights to converted GMPs would be lower than the current GMP priority; thus non-pensioners with GMP rights might end up with a lower percentage. The actuarial equivalence requirement would also need to ensure that any resulting conversion complied with the equal treatment requirements.

As with the abolition option, action would be needed to prevent double provision. Inland Revenue would need to keep records of notional GMPs to 
enable contracted-out deductions from SERPS/S2P still to be made.

Conversion could mean that the equal treatment ratchet effect would operate. Thus, whenever a man's rights were actuarially converted, a similar actuarial calculation as though the member were a woman would need to be undertaken, and vice versa, to ensure that for applicable post-Barber ${ }^{6}$ periods, the member received the higher on the 'equalisation up' principle.

\section{Option of transfer of GMP rights to state scheme}

Under this option schemes would be permitted to buy back GMP rights into SERPS/S2P, but would then be liable to pay the excess over GMP. Some pensioners would receive lower pensions, as GMPs can exceed the equivalent SERPS entitlement. It would also affect both pensioners abroad in those states where UK state benefits are frozen and pensioners in hospital who are subject to state pension downrating. The effect on wind-up would be less for members than for conversion, as the SERPS would be payable, irrespective of the scheme funding. However, the cost of buy-back of GMP rights could reduce the remaining assets to a level that would lead to lower pensions for members. The remaining scheme benefits would need to be equalised, as the cost of buying back could leave the remaining rights unequal for men and women.

The Government Actuary's Department (GAD) would be required to produce buy-back tables analogous to earlier state scheme premiums. The premiums would in the short term increase the inflow to the National Insurance Fund, but would ultimately impose a greater unfunded liability, which successive governments have attempted, through contracting out, to avoid.
The transfer option would have the advantage of permitting schemes to get rid once and for all of GMPs and the administrative obligations that they create for both scheme administrators and the Inland Revenue. However, the option could lead to lower aggregate pensions for members and a considerable one-off administrative burden of calculating the premiums.

\section{Other GMP options}

The DWP has invited any other suggestions for overcoming the GMP problem. One possible option would be a voluntary conversion to the reference scheme test in respect of all pre-1997 contracted-out employment under a COSR scheme, albeit with a limitation on statutory indexation to the applicable GMP indexation level. In most cases, the value of total scheme benefits exceeds the value of the GMPs. Exceptionally, where at conversion the GMP level exceeded the reference scheme test, schemes could be required to provide a one-off actuarially calculated augmentation. As the conversion would not be compulsory, it would avoid funding problems where GMP rights had been bought out, or were in a frozen scheme, as these could remain GMPs. The conversion would overcome the problem of equalisation of GMPs and remove one of the major problems for transfers and wind-ups. Anti-franking would then apply only where the GMPs were not converted.

Although the DWP has considered conversion to the reference scheme test in place of the GMP requirement, officials rejected that idea as being retrospective legislation. However, it does not seem to be retrospective if conversion is an option with, where appropriate, actuarial augmentation. Past rights are not being taken away and 
there would be no compulsion on anyone to change.

\section{Other contracting-out issues}

The Government seeks views on proposals to remove restrictions relating to the age at which contracted-out rights are payable and rules preventing commutation of contracted-out rights to lump sums. It also proposes doubling the trivial commutation level from $£ 260$ p.a. to $£ 520$ p.a., albeit with restrictions (possibly age) when trivial commutation may occur.

The Government is considering abolishing contracting-out mixed-benefit schemes (COMBS) and, if it does, wonders whether transitionally COMBS should be permitted to continue, or whether existing COMBS rights should be converted to either $\mathrm{DB}$ or defined contribution (DC) rights. It seems premature to abolish COMBS at a time when the Inland Revenue is proposing a radical revision of the rules for tax approval, permitting new possibilities for scheme design. New scheme design in the light of the Inland Revenue's changes may well lead to a greater desire for schemes to contract out as COMBS.

\section{Safeguarded rights}

The Government proposes to abolish safeguarded rights on the basis that court orders and family law provide sufficient protection to ex-spouses. Though unlikely to create much administrative saving in view of the limited number of pension sharing orders, this is nonetheless a welcome simplification.

\section{Equivalent pension benefits (EPBs)}

The Government proposes to permit full commutation without a member's consent where the benefit consists solely of EPBs. ${ }^{7}$ In other cases commutation of EPBs will be permitted with the member's consent.

\section{Greater flexibility for schemes}

\section{Modification and s. 67}

Section 67 of the Pensions Act 1995 prevents any change to scheme rules unless either the members concerned consent to the change, or the scheme actuary has certified that the change would not be detrimental to members' accrued rights. The Pickering report pointed out that this left many employers who could not continue to meet unsustainable costs the option of winding up the scheme and/or moving to a DC arrangement. Even amendments, which could be justified as being manifestly in the members' interest, are prevented by s. 67. Hence Pickering recommended the replacement of s. 67 by an 'equivalent value' test, under which members' rights in respect of past service could be amended without consent, provided that the overall value of the replacement is expected to be of equivalent value.

The Government rejects the Pickering proposal for an equivalent value replacement, but is prepared to agree to some minor adjustments at the edges. This would be achieved by:

- clarifying the current wording of s. 67

- allowing schemes to make changes providing that the actuarial value of the change did not exceed a certain percentage, possibly 5 per cent, of a member's total accrued rights

- requiring that where the modification resulted in a reduction in the value of the member's rights, those foregone would be replaced by something of actuarially equivalent value. 
The Government considers that this would permit minor restructuring of rights. For instance, (the Government's example) if two schemes, one paying dependants' benefits to age 16 and the other to age 18 , were merged, the merged scheme could adopt age 16, if it provided a replacement benefit of the same actuarial value as the loss to those hitherto having the 'to age 18 rule'. However, schemes would not be able without consent to convert a member's accrued defined benefit rights to defined contribution as that would mean converting not 5 per cent, but 100 per cent of members' rights.

The Government's proposal is disappointing. It fails to address the fundamental problem that section 67 causes for modifying schemes. While allowing schemes to make minimal changes, it may still leave winding-up existing schemes as the only option for employers who can no longer afford their current arrangements. The issue is highlighted by the Inland Revenue's proposals to apply the same regime to defined benefit and defined contribution schemes. If the Inland Revenue provides tables for the valuation of defined benefit rights in comparison with defined contribution rights, the objection to converting from DB to DC has far less relevance than hitherto.

\section{Member-nominated trustees (MNTs)}

Legislation is already in place, albeit not commenced pending consideration of the Pickering report, to abolish the employer opt-out from the MNT requirements. The Government has stated its intention not to resile from the principle. Instead, they propose simplification of the proposed regime by requiring schemes to have MNTs as one third of the trustees, while removing the detailed statutory rules on how to reach that objective.
The Government has therefore put forward two options: an option of the minimum legislation needed to achieve the objective; or an alternative with an additional provision requiring the MNT arrangements to be 'fair and open'.

Under the former, the pensions regulator would issue guidance on good practice, but, although the regulator would have power to enforce the MNT requirement, the guidance would not be enforceable. Rules and procedures drawn up by the trustees would be simple, but might be seen by some members as unfair. Under the latter option, compliance with the regulator's guidance would deem the procedures to be 'fair and open'.

The DWP's technical paper has been supplemented by a further consultation paper, which explains that guidance to be issued by the new regulator would cover issues currently in primary or delegated legislation. These would include the nomination and selection procedure, including whether the employer would have the right of veto, non-members would be eligible for nomination, and there could be geographical or other constituencies and/or selection panels. It would also cover the meaning of 'fair and open' (if that option were adopted) and 'reasonable time', terms of office, removal and how to deal with unfilled vacancies.

Commencement would be before November 2005 and as soon as possible after Royal Assent to an implementing Bill.

\section{Internal dispute resolution (IDR)}

The Government proposes a welcome simplification of the current IDR procedures by requiring that:

- all schemes must have a published IDR procedure, but can choose 
between a one or two stage procedure

- the process must allow complainants access to the trustees

- the decision must be given within a prescribed time limit (six months is suggested) and, if not, the member can complain to the Pensions Ombudsman

- the complainant must be told that the Pensions Advisory Service (OPAS) can assist and about the Pensions Ombudsman's role.

\section{Preservation and transfers}

\section{Preservation}

The Government proposes to retain the current requirements for preservation and revaluation, but introduce immediate vesting (see below). They propose, however, to simplify the provisions, eg removal of the money purchase uniform accrual provision. If there were to be a change to the primary legislation, it would be more appropriate for preservation to be brought within the overriding legislation provisions analogous to the overriding legislation in respect of revaluation and transfers.

\section{Transfers}

Following the replacement of the MFR by scheme-specific funding arrangements, the current requirement for a cash equivalent transfer value (CETV) from a $\mathrm{DB}$ scheme to be at least the value of the rights using the MFR funding basis will be obsolete. The Government therefore proposes a less prescriptive replacement. Trustees should decide how CETVs should be calculated on the advice of the scheme actuary and with no statutory underpin. In principle, CETVs should be calculated on a consistent basis that is fair to all members. The Government believes that there is scope for simplification of current provisions and that changes to the contracting-out arrangements would ease current delays.

It is clear that the abolition of the MFR will require an amendment to the transfer calculation, and it seems reasonable to require the trustees to adopt a consistent basis fair to all. It is less clear that contracting-out changes will overcome current problems as regards transfers. Equalisation of GMPs has still not been addressed. Until it is, many schemes will continue to refuse transfers in. Equally, while contracting-out rights have to be identified separately, calculation of CETVs will remain unnecessarily complex.

\section{Communication with scheme members}

\section{General disclosure}

The Government seeks rationalisation of the current disclosure requirements, in particular, the removal of many of the current time limits for disclosure and their replacement by 'within a reasonable time'. In certain circumstances mandatory requirements to provide information to members would be replaced by a requirement to provide information on request. The Government's proposals are welcome, but as recently as April 2002 the Winding Up Notices and Reports Regulations ${ }^{8}$ amended 'as soon as reasonably practicable' to 'within the period of one month'. The DWP view appears to have altered since then.

During consideration of the post-Pensions Act regime, DSS officials were pressed to replace regulations on disclosure with a code of best practice, outlining principles under which disclosure was needed and what members would wish, and needed, to know. 
Whereas the Government accepts that in the field of MNT the objective should be specified, while leaving trustees to decide how to achieve it, in the field of disclosure, the Government still appears to require detailed, albeit simpler, regulations. It would be preferable for the Government to state the objective and then either for a code of best practice to be adopted or for trustees to be given the choice of means of meeting that objective.

\section{Statutory money purchase illustrations (SMPI)}

Not altogether surprisingly, the DWP is unwilling to withdraw the requirement for DC schemes to provide SMPIs in relation to specified dates on or after 6th April, 2003. They claim that, as schemes will have been expending time and money on establishing SMPI procedures, it would be inappropriate at this stage to abolish or change the provision.

\section{Pensions on divorce}

The Government proposes the following simplifications:

- consolidation of pension sharing regulations for England and Wales

- repeal of superfluous requirements in the Family Law Act 1996

- rationalisation of destinations for pension credit

- removal of the default option regarding transfers out of pension shares

- removal of pension credit ill health and serious illness provisions

- alignment of normal benefit age for pension credit benefit in occupational pension schemes (OPS) and personal pension schemes (PPS)

- abolition of safeguarded rights

— the rebuilding limits removed subject to the proposed new Inland Revenue rules.

Anything to simplify the current divorce provisions is welcome. However, short of abolishing pension sharing and earmarking, which is not on the agenda, it is difficult to see how the current administrative complexity can be avoided.

\section{Protection in the case of wind-up}

\section{Rebalancing priorities between pensioners and non-pensioners}

The Government believes that the current statutory rules applicable when a defined benefit scheme is wound up with insufficient assets to meet its liabilities in full work unfairly to non-pensioner members approaching retirement or with long pensionable service under the scheme. Accordingly, they propose to retain a statutory priority order, but to introduce a new category of priority to cater for this group. Table 2 describes the transitional priority order before 6th April, 2007, the final priority order thereafter and the Government's proposed changes.

As an alternative approach or in addition to the above, the Government has proposed the introduction of a capping system to discourage directors and highly paid executives from taking early retirement shortly before the scheme starts to wind up. Under this proposal, either those who had retired within 12 months prior to the scheme starting to wind up, or possibly all pensioners, would be subject to the following provisions on priority:

- those with pensions up to $£ 30,000$ p.a. would retain their pensioner status and pensioner priority, but - those with pensions higher than 
Table 2:

\begin{tabular}{|c|c|c|}
\hline $\begin{array}{l}\text { Transitional priority order } \\
\text { (until 5th April, 2007) }\end{array}$ & $\begin{array}{l}\text { Final priority order } \\
\text { (from 6th April, 2007) } \\
\text { ne expenses and debts to third }\end{array}$ & $\begin{array}{l}\text { Government's Green Paper } \\
\text { proposals for final order } \\
\text { Irties }\end{array}$ \\
\hline $\begin{array}{l}\text { Additional voluntary } \\
\text { contributions }\end{array}$ & $\begin{array}{l}\text { Additional voluntary } \\
\text { contributions }\end{array}$ & $\begin{array}{l}\text { Additional voluntary } \\
\text { contributions }\end{array}$ \\
\hline $\begin{array}{l}\text { Benefits secured by the trustees } \\
\text { under a pre-6th April, } 1997 \\
\text { insurance contract to meet } \\
\text { members' (or survivors') pension } \\
\text { entitlement and the contract } \\
\text { cannot be surrendered or the } \\
\text { surrender value is not more than } \\
\text { the liability. }\end{array}$ & $\begin{array}{l}\text { Benefits secured by the trustees } \\
\text { under a pre-6th April, } 1997 \\
\text { insurance contract to meet } \\
\text { members' (or survivors') pension } \\
\text { entitlement and the contract } \\
\text { cannot be surrendered or the } \\
\text { surrender value is not more than } \\
\text { the liability. }\end{array}$ & $\begin{array}{l}\text { Benefits secured by the trustees } \\
\text { under a pre-6th April, } 1997 \\
\text { insurance contract to meet } \\
\text { members' (or survivors') pension } \\
\text { entitlement and the contract } \\
\text { cannot be surrendered or the } \\
\text { surrender value is not more than } \\
\text { the liability. }\end{array}$ \\
\hline $\begin{array}{l}\text { Pensions and other benefits in } \\
\text { payment, plus death benefits in } \\
\text { respect of current pensioners } \\
\text { (excluding increases). }\end{array}$ & $\begin{array}{l}\text { Pensions and other benefits in } \\
\text { payment, plus death benefits in } \\
\text { respect of current pensioners } \\
\text { (excluding increases). }\end{array}$ & $\begin{array}{l}\text { Pensions and other benefits in } \\
\text { payment, plus death benefits in } \\
\text { respect of current pensioners. }\end{array}$ \\
\hline $\begin{array}{l}\text { Accrued rights to EPBs, GMPs, } \\
\text { protected rights, s. } 9(2 \mathrm{~B}) \text { rights, } \\
\text { and safeguarded rights and } \\
\text { refunds of contributions to } \\
\text { those with less than two years' } \\
\text { service. }\end{array}$ & $\begin{array}{l}\text { Any liability for rights to } \\
\text { pensions or other benefits } \\
\text { accruing to or in respect of } \\
\text { members (excluding increases) } \\
\text { and refunds of contributions to } \\
\text { those with less than two years' } \\
\text { service. }\end{array}$ & $\begin{array}{l}\text { Accrued pension or other } \\
\text { benefits and future benefits } \\
\text { relating to pension credit } \\
\text { (excluding increases) for those } \\
\text { approaching (ie within ten years) } \\
\text { of pension age } \\
\text { OR } \\
\text { Accrued pension or other } \\
\text { benefits, future benefits relating } \\
\text { to pension credit (excluding } \\
\text { increases) of those who have } \\
\text { been a member of the pension } \\
\text { scheme for above a specified } \\
\text { number of years. }\end{array}$ \\
\hline $\begin{array}{l}\text { Increases to pensions and other } \\
\text { benefits in payment, and to } \\
\text { benefits secured under pre-1997 } \\
\text { insurance contracts (as above). }\end{array}$ & $\begin{array}{l}\text { Increases to pensions and other } \\
\text { benefits in payment and to } \\
\text { future pensions and other } \\
\text { benefits. }\end{array}$ & $\begin{array}{l}\text { Any liability for rights to } \\
\text { pensions or other benefits } \\
\text { (excluding increases) accruing } \\
\text { to or in respect of members } \\
\text { (other than those within either } \\
\text { ten years of pension age or } \\
\text { who have been members for } \\
\text { the requisite number of years, } \\
\text { as above) and refunds of } \\
\text { contributions to those with less } \\
\text { than two years' service. }\end{array}$ \\
\hline $\begin{array}{l}\text { Increases to EPBs, GMPs, } \\
\text { protected rights, s. } 9(2 B) \text { rights } \\
\text { and safeguarded rights. } \\
\text { Any other liability for pensions } \\
\text { (including increases) accruing to } \\
\text { or in respect of members or } \\
\text { future benefits attributable to } \\
\text { pension credit. }\end{array}$ & & $\begin{array}{l}\text { Increases to pensions and other } \\
\text { benefits in payment and to } \\
\text { future pensions and other } \\
\text { benefits. }\end{array}$ \\
\hline
\end{tabular}

\&30,000 p.a. would retain their pensioner status and pensioner priority in respect of the first $\$ 30,000$ of their pension, but in respect of the excess they would be treated for priority purposes as non-pensioners, or

- those with pensions higher than f30,000 p.a. would retain their pensioner status and pensioner priority 
in respect of the first $£ 30,000$ of their pension, but they would qualify for the excess over $\mathcal{2} 30,000$ if and when the full accrued rights of non-pensioners had been met.

To alter the size of the slices of a small cake will mean that some members will obtain smaller, or no, slices to compensate for the larger slices of others. The Government recognises the problem of those approaching pension age or with long service losing out because of the current priority rules, but to improve their position would worsen the lot of other younger or shorter service members.

To base the priority on length of service, while at first sight reasonable, could particularly affect those recruited later in their working life by, inter alia, the promise of a good pension. They might have left their previous employment with a good pension scheme in anticipation of continuing to accrue a good pension, but find themselves in a worse position than others who had left the employer some years before, albeit with more pensionable service. While younger members would have the opportunity subsequently to build up pension rights elsewhere, this is not the case of those who are older but have been members of the scheme for a shorter period. As regards capping, the capping would apply to the post-commutation pension rate. If so, a quarter of the value of the individual's rights would already have been eaten up if, as would be likely, the member had commuted to a tax-free lump sum.

\section{Amending the priority order of creditors}

In relation to companies that become insolvent with debts to the pension scheme, the Government proposes to introduce a new category of creditor. Under this pension schemes would still be lower in the pecking order than preferential and secured creditors, but would be raised above other unsecured creditors. The Government's concern is what, if any, adverse effect this would have on other unsecured creditors, including trade suppliers, consumers and employees, who could lose out, and companies themselves who might find it more difficult or more costly to obtain loans.

From a solely pensions point of view, any change in the priority order that would improve the position of pension funds as creditors of insolvent employers would be welcome. However, other considerations may be thought to outweigh the benefit from an improvement in the status of pension schemes.

\section{Insolvent employers}

The Government has suggested as an alternative to the above the introduction of either an insurance or centralised 'clearing house' arrangement. Under the former, possibly through a central discontinuance fund, additional protection could be funded through reduced benefits or higher contributions to meet the insurance premiums. Under the latter, the Government suggests that, as an alternative to purchasing individual annuities on wind-up, members could choose to pay the funds they receive into clearing house arrangements. The clearing house could then negotiate with providers the purchase of deferred annuities, which by spreading administrative costs and the risk would be more advantageous than individually purchased annuities.

A central discontinuance fund has been proposed, and rejected, a number of times. It has always been the 
objection of (principally large) well-run schemes that with an insolvency insurance requirement they (and the sponsoring employers and members) would effectively be subsidising (largely small) badly run schemes, which are far more likely to become insolvent. Equally for defined benefit schemes, low earners would also be subsidising high earners, unless either the capping proposed above limited the effect or there was a cap on the level of insurance. The existence of a central discontinuance fund could have the effect of the original provisions applicable to the Pension Benefit Guaranty Corporation (PBGC) in the USA. Trustees were implicitly encouraged to operate an imprudent investment policy on the basis that, if successful, benefits would be higher or contributions lower, but, if unsuccessful, the PBGC would, and did, pick up the tab. This could apply to a central discontinuance fund at the expense of more prudent schemes.

A clearing house, also rejected in the past, seems unlikely to be able to buy annuities at a sufficiently more advantageous rate than individual trustees, bearing in mind the additional administrative cost. If, however, a significant benefit in establishing such an arrangement could be identified, a clearing house might be beneficial, provided that participation was voluntary.

\section{Improved compensation arrangements}

The Government proposes to increase from 90 per cent to 100 per cent the compensation provided by the Pensions Compensation Board (PCB) to those schemes and in respect of those members where the 90 per cent level still applies (ie for DC schemes and DB members more than ten years from normal pension age). They do not propose to amend the criteria for payment of compensation.
However, this is perhaps the opportunity to monitor the compensation scheme to see whether the criteria for compensation need to be amended.

\section{Solvent employers}

Changes implemented in March 2002 required solvent employers who choose to wind up their scheme to ensure that the scheme has sufficient assets to meet:

— the trustees' estimate of all likely winding-up expenses

- the actual costs of buying annuities for pensioners guaranteeing full pensions

- the transfer value of the accrued benefits of non-pensioners, calculated on a MFR basis.

The replacement of MFR by a scheme-specific funding requirement and the introduction of a requirement for trustees to determine transfer values on a basis that is fair to all (see above) means that the transfer value for non-pensioners, and so the cost to employers, may increase.

The Government has put forward two options designed to improve the position of members where a scheme is wound up. These are:

- a 'full buy-out', under which employers would be required to provide sufficient funds on wind-up to allow annuities (deferred for non-pensioners) guaranteeing full pension to be bought for all scheme members; or

- a 'partial buy-out', under which employers would be required to provide sufficient funds on wind-up to allow annuities (deferred for non-pensioners) guaranteeing full pension to be bought for pensioners 
and other scheme members approaching retirement, but with younger workers being entitled to a cash equivalent transfer value on the post-MFR basis determined by the trustees.

The replacement of the MFR as a basis for calculating transfer values will mean that, irrespective of whether either of the Government's two buy-out options is adopted, the cost of meeting liabilities on wind-up will alter. The increase (or reduction) in cost will depend on the relationship between the trustees' determination on how future transfer values are to be calculated and the present MFR basis.

As regards the Government's buy-out options, it would appear that the Government is attempting, probably after too many horses have bolted, to reduce the number of employers who wind up DB schemes. However, the change would not affect those employers who close their DB scheme to new entrants, but continue with a closed or frozen scheme. There may, however, be a knock-on effect if the employer and trustees cannot agree the scheme-specific funding basis or the contribution rates in the schedule of contributions and accordingly use their proposed powers to force a wind-up of the scheme. Employers might then be required to meet the full buy-out cost at a time when they were not expecting to. (Alternatively, this may act as a stick to force agreement to the funding arrangements or contribution rate if the trustees' carrot does not work.)

For employers, if one of the Government's buy-out options is to be imposed, the partial buy-out would be cheaper. However, it could result in younger members drawing a lower pension on retirement. For members, the full buy-out guarantee would be preferable, but to impose it could have the effect of bringing some hitherto solvent employers into insolvency and so leading to a lower pension for younger members than the partial buy-out option. The Government states that its aim is not to increase the overall burden on employers providing pensions. If there has to be one of the alternative buy-out options, the partial buy-out would better achieve that objective.

\section{Speeding up winding-up}

The Government refers in the Green Paper to the new obligations introduced in April 2002 in relation to reports to the Occupational Pensions Regulatory Authority (Opra). It seeks views on other options that could speed up winding up. It also seeks views on the Pickering proposal to permit the liabilities in respect of members more than ten years from normal retirement age to be discharged with consent to a stakeholder or other DC pension arrangement.

Winding-up would be expedited if the current requirements in relation to GMPs were simplified. Many schemes were fairly recently faced with inordinate delays in obtaining information from the Inland Revenue, which considerably delayed wind-ups. (It is perhaps ironic that DWP provided for penalties on schemes and trustees that delayed issuing information to members, but no penalty was imposed on the Inland Revenue for longer delays in providing contracted-out information.) A further complication in winding-up arises from DWP's failure to bring in provisions to equalise GMPs. Resolving these two issues would do much to improve wind-ups.

As regards the Pickering proposal, any means of discharging liabilities more 
Table 3:

\begin{tabular}{ll}
$\begin{array}{l}\text { Option 1: TUPE occupational pensions proposals } \\
\text { Private to private business transfers }\end{array}$ \\
\hline Type of pension & \\
\hline Old employer provides: & New employer provides as minimum: \\
DB scheme & $\begin{array}{l}\text { Alternative DB scheme } \\
\text { DC scheme with comparable } \\
\text { provided by old employer }\end{array}$ \\
& $\begin{array}{l}\text { Alternative DB scheme } \\
\text { DC scheme with comparable }{ }^{10} \text { contribution to that } \\
\text { provided by old employer }\end{array}$ \\
\hline DC scheme & \\
&
\end{tabular}

Table 4:

\begin{tabular}{ll}
\hline $\begin{array}{l}\text { Option 2: TUPE stakeholder/GPP proposals } \\
\text { Private to private business transfers }\end{array}$ \\
\hline Type of pension \\
\hline Old employer provides: & New employer provides as minimum: \\
DB scheme or & GPP with a contribution of at least $X$ per cent \\
DC occupational scheme & Stakeholder scheme with a contribution of $X$ per cent \\
GPP or stakeholder scheme & GPP with a contribution of at least $X$ per cent \\
with employer's contribution & Stakeholder scheme with a contribution of $X$ per cent \\
\hline
\end{tabular}

Note: The Government seeks views on what percentage the $\mathrm{X}$ should be. It does not necessarily equate with the contributions that the old employer paid.

simply would be welcome and make wind-ups quicker to complete. Ideally it would be preferable to permit transfers to stakeholders schemes et al. without consent, but, in the light of the DWP view on s. 67 replacement, this seems unlikely to be acceptable.

\section{Transfer of Undertakings (Protection of Employment) - TUPE}

The Government proposes to remove the current derogation in the TUPE Regulations in respect of pension provision. In doing so, they intend to take account of their support for business flexibility and the need to protect employees against the insecurity that a TUPE transfer creates. They already apply TUPE to transfers from the public service to the private sector. Accordingly they have produced two tables outlining possible options if the derogation is removed: the former (Table 3) requiring the new employer to provide an occupational scheme; the latter (Table 4) a group personal pension (GPP) or stakeholder scheme.

The peculiarity in the Government's position is that they wish to remove the pension derogation and require the receiving employer to provide one of the alternatives in the table above, but that employer would be able to wind up the replacement scheme almost at once. Thus there would in effect still be a derogation, but with a time lag.

Possible problems arising from the Government's proposals are:

- if the transferring employer had a non-contributory scheme, the receiving employer would appear to be required to provide the same contributions as the former, even if the latter's scheme for existing employees was a contributory scheme and vice versa; 
- if the transferring employer's DB scheme was in surplus and the employer either had a contribution holiday or the schedule of contributions required a very low percentage employer contribution, the same contribution by the receiving employer to a DC scheme would lead to a considerably lower pension accrual;

- a transfer from an employer with a DB scheme to an employer with a DC occupational, GPP or stakeholder scheme with employer contributions at either the same rate as the former employer or X per cent would benefit younger employees to the detriment of older employees. This would be likely to be seen by the latter as unfair;

- notwithstanding reference 11 , it is unclear what the position would be if one employer's scheme was contracted-out, but the other was not. It is unclear whether the requirement for X per cent to a GPP or stakeholder would apply where the scheme was the member's 'chosen' APP scheme, or the member was in S2P, or both, or whether it would be adjusted. ${ }^{11}$ For lower paid workers the difference in treatment of S2P under respectively COMPS and APPS could affect whether it would be preferable to be in a DC occupational or a GPP or stakeholder scheme;

- no accrual rate is specified for a DB scheme for the receiving employer. Thus the transferring employer could have had a 1/60ths accrual rate, but the receiving employer have a $1 / 120$ ths or less. Similarly the transferring employer might have provided a high percentage contribution rate to a DC scheme, while the receiving employer has a very low accrual DB scheme;

- the position if the transferring members were unhappy about the receiving employer's choice of stakeholder or GPP provider; or

- nothing is said about transfers between the two schemes. If there are to be such transfers, are they to be on the bulk transfer or individual transfer basis?

\section{Immediate vesting and transfers without consent}

\section{Immediate vesting}

Currently occupational pension scheme rights vest after two years' pensionable service. The Government has adopted the Pickering recommendation of requiring immediate vesting, but with the right (see below) for de minimis transfers without consent.

Immediate vesting raises a number of issues:

- schemes are likely to be faced with more small amounts (marginally above the proposed de minimis) of pension rights of deferred members. This will add to administrative complexity and cost, especially as regards the cost of satisfying the disclosure requirements for those who currently would no longer be scheme members;

- will schemes still be permitted to operate waiting periods before membership? If so what is the position of those who leave after less than two years? Would it make any difference if no rights would accrue in respect of the two-year period or if accrual was backdated to the start of the employment once the two years' waiting period had been served. (Employers are required to designate a stakeholder scheme if employees are not eligible to join the OPS after 12 months' employment. This is likely in practice to restrict the length of any waiting period.); 
— what will be the position of contributions equivalent premiums (CEPs) if immediate vesting is introduced? Will the rights of members of contracted-out schemes be able to be bought back into S2P if they have served less than two years in the employment? What would be the position if, before payment of a CEP, the accrued rights exceed the de minimis level, but, after payment of a CEP, they are below that level?

\section{De minimis transfers without consent}

The Government has adopted the principle recommended by Pickering that, as a counterbalance to immediate vesting, trustees should have the right to transfer de minimis amounts to a default stakeholder arrangement without the member's consent. However, the principle has been watered down since Pickering. Instead a transfer could be made of a de minimis amount if:

- members were told when they left the scheme that their rights would be transferred to a stakeholder scheme after six months, unless they objected

- the member concerned took no action to object to a transfer in the six months (no specific objection would be taken as acquiescence) and did not ask for the rights to be transferred elsewhere

- six months had elapsed since the member left pensionable service.

Failure to notify members immediately after leaving of the possibility of a transfer to a stakeholder scheme would deny trustees the right to make such a transfer without specific consent.

Although Pickering suggested the de minimis level should be set at $£ 10,000$, the Government considers that too high and suggests $\mathcal{E} 7,000$. Alternatively the
Government suggests that de minimis transfers should apply for rights of up to five years' pensionable service. The Government has sought views as to whether trustees should be required to nominate a specific stakeholder scheme to which such transfers would be made, unless a deferred member nominated any other.

Although apathy is likely to result in most members with de minimis rights not objecting to a transfer to a stakeholder pension, the right to object is likely to mean that schemes are still left with insignificant amounts in respect of objectors, which are costly and proportionately time-consuming to administer. It would be preferable to allow schemes to permit de minimis transfers without consent in all cases. To avoid the objection that members would be unaware of the situation or that the $\mathrm{DB}$ risk to the employer was being passed to a DC risk to themselves, it might be appropriate for a requirement that de minimis transfers without consent would be permitted only where:

- scheme rules provided for them

- members did not ask for a transfer to another arrangement that would accept it

- members were told in the initial disclosure pack/booklet that this is what would happen if they left pensionable service after less than $n$ years pensionable service or with accrued rights of less than the specified amount.

This would ensure that schemes could get rid of all de minimis amounts.

It would seem more appropriate for a fixed sum as the maximum de minimis amount than for length of service. The amount that accrued from five years' service could vary considerably depending on salary and accrual rate, whereas the 
fixed maximum would apply irrespective of the length of service and would be at a level, preferably $£ 10,000$, that would avoid disproportionate pro rata cost. It seems reasonable for trustees to be required to designate a specific stakeholder scheme applicable for all such transfers to avoid accusations of bias to particular members. However, they should be required to review their designation from time to time in the light of scheme performance and should be permitted to change the designated scheme, provided that this was notified to members.

\section{Compulsory scheme membership}

The Government is considering reversing the provision in the Social Security Act 1986 removing from employers the right to make pension scheme membership a condition of employment. They suggest allowing employers voluntarily to reintroduce that requirement for new entrants.

It is unclear how many employers would wish to reintroduce this requirement. One of the original justifications was that administratively it was cheaper to operate a payroll system with all employees in, rather than some in and others out. The reintroduction of the requirement would not achieve that objective as existing employees would not be covered - to do so would mean an alteration of their contract of employment and some would already have made alternative provision, eg through PPS.

Although it might be beneficial to employers to have the right to make scheme membership a condition of employment and this would bring within pension cover many workers who might otherwise have chosen not to make pension provision. However, it might be appropriate to restrict the right to employers who provided a pension scheme that satisfied certain specified criteria. The removal in $1986^{12}$ of the ability to make scheme membership a condition of employment coincided with the introduction of contracted-out money-purchase schemes (COMPS). It was felt at the time to force an employee, particularly an elderly employee, to become a member of a rebate-only COMPS, when the member could otherwise have accrued higher benefits under SERPS, was unjustifiable. Similar considerations must be taken into account in any possible reintroduction of this provision.

\section{Disclaimer}

The views expressed in this paper are those of the author and it should not be assumed that they necessarily represent the views of Lane Clark \& Peacock LLP as a firm.

\section{References}

1 'Simplicity, security and choice: Working and saving for retirement', Cm 5677, December 2002.

2 'Simplicity, security and choice: technical paper', DWP, December 2002.

3 'Simplifying the taxation of pensions: increasing choice and flexibility for all', HM Treasury \& Inland Revenue, December 2002.

4 Pickering, A. (2002) 'A simpler way to better pensions', independent report, July.

5 See The Child Support, Pensions and Social Security Act 2000, Schedule 5, Part II.

6 Periods following the judgment of the European Court of Justice on 17th May, 1990 in the case of Barber $v$ Guardian Royal Exchange, which ruled that Article 119 (now 141) of the EEC Treaty required equal retirement conditions for men and women in occupational pension schemes.

7 Rights accruing under the pre-1975 contracting-out regime.

8 See The Occupational Pension Schemes (Winding Up Notices and Reports etc) Regulations 2002 (SI 2002/459), reg. 3.

9 Adjusted, if necessary for the loss of the NI rebate if contracted in and where comparability is determined over the lifetime of the fund.

10 Adjusted as above.

11 Unlike the position with a contracted-out OP scheme, there would be no difference in NICs either way. If the scheme were the member's 'chosen' scheme more net contributions would be paid into the GPP or stakeholder scheme, but the member would not accrue S2P, but, if not, less would accrued in the scheme, but the member would qualify for S2P.

12 By the Social Security Act 1986. 